\title{
STUDIES ON COPPER METABOLISM. XXIII. PORTAL (LAENNEC'S) CIRRHOSIS OF THE LIVER ${ }^{1}$
}

\author{
By C. J. GUBLER, H. BROWN, H. MARKOWITZ, G. E. CARTWRIGHT, AND \\ M. M. WINTROBE \\ (From the Department of Medicine, University of Utah College of Medicine, and the Veterans \\ Administration Hospital, Salt Lake City, Utah)
}

(Submitted for publication February 25, 1957; accepted March 22, 1957)

Disorders in the metabolism of copper have been a constant finding in hepatolenticular degeneration, a disease which involves both brain and liver (1-4). Recently, the neurologic manifestations associated with cirrhosis of the liver have received attention (5). It is, therefore, natural to inquire if derangements of copper metabolism are present in subjects with cirrhosis of the liver and if these derangements are of any importance in the pathogenesis of the disease, particularly in relation to the development of neuropsychiatric manifestations.

This idea is in no way original. Mallory $(6,7)$, about 30 years ago, found the copper content of alcoholic beverages to be high and suggested that the excessive deposition of copper in the liver might be the etiologic factor in the production of pigment cirrhosis. More recently, Adams and Foley (8) have considered the possible relationship between hepatic coma and hepatolenticular degeneration and have discussed the similarities and dissimilarities between these two conditions in which both liver and brain disease are found.

There is a limited amount of information which suggests that in at least some patients with cirrhosis of the liver there is hypercupremia (1, 911), hypercupriuria (1) and an increased concentration of copper in the liver (12-14). Porter and Adams (15) analyzed the copper content of the putamen and liver of 11 cases of chronic liver disease dying in coma and of 11 control cases. No difference was found between the two groups in the copper content of the putamen but the liver copper was increased in two-thirds of the patients dying in hepatic coma.

In none of the studies referred to above were values presented for non-ceruloplasmin copper in serum or spinal fluid copper, or for urine copper

1 This investigation was supported by a research grant (C-2231) from the National Cancer Institute, National Institutes of Health, United States Public Health Service. after the administration of BAL (2,3-dimercaptopropanol). Such studies would give an estimate of the size of the fraction of copper which is loosely bound to protein. It seemed possible that this fraction of copper rather than the more tightly bound fraction might be related to the neuropsychiatric manifestations of portal cirrhosis of the liver.

The purpose of this paper is to present the results of studies of copper metabolism in patients with portal cirrhosis of the liver. Values for total serum copper, ceruloplasmin, non-ceruloplasmin copper, spinal fluid copper, urine copper, urine copper following the administration of BAL, and tissue copper are presented for control subjects and for patients with cirrhosis. Because of the suggestion that thioctic acid (6,8-dithiooctanoic acid) may be of value in the therapy of hepatic coma $(16,17)$, and because of the possibility that thioctic acid, a disulfide compound, may chelate with copper, the influence of this agent on serum and urine copper was also studied.

\section{METHODS}

The patients were selected from the wards of the Salt Lake General Hospital and the Veterans Administration Hospital. All gave a history of prolonged and excessive intake of alcohol and all presented clinical as well as laboratory evidence of severe cirrhosis of the liver. A subtotal gastrectomy had been performed five years previously and a portal-caval shunt was carried out two years previously on patient $\mathrm{K}$. $\mathrm{H}$. All of the patients were males with the exception of $\mathrm{I}$. O. Of the patients on whom an autopsy was performed, all died in hepatic coma except A. S. and P. S. These two patients died following hemorrhage from esophageal varices.

The normal subjects used for blood copper studies were healthy laboratory personnel or medical students. The "normal subjects" given BAL were hospitalized psychiatric patients without psychoses or demonstrable organic disease. The five "normal subjects" on whom autopsies were performed were all adult males who died following traumatic injuries.

Total serum copper was measured by the method of 
Gubler, Lahey, Ashenbrucker, Cartwright, and Wintrobe (18). The amount of copper in the spinal fluid was determined by the technic employed for serum. Ceruloplasmin was measured immunologically by the use of rabbit antihuman ceruloplasmin serum which had been absorbed with serum from a patient with Wilson's disease (3).

Because of the deep icterus of the serum from most of the patients with cirrhosis of the liver, the "direct-reacting" copper could not be measured by the usual technic of adding sodium diethyldithiocarbamate to serum (19). Therefore, the "direct-reacting fraction" was calculated by multiplying the concentration of ceruloplasmin ( $\mu \mathrm{g}$. per $100 \mathrm{ml}$.) by 0.32 per cent (the theoretical concentration of copper in ceruloplasmin) and subtracting the product from the total serum copper ( $\mu \mathrm{g}$. per $100 \mathrm{ml}$.). In this paper this fraction is referred to as the "non-ceruloplasmin" copper in serum. This method gives values in normal subjects which are lower than those obtained by the "direct" method. As discussed previously (3), this may be due to the fact that the antiserum used contains antibodies to proteins other than ceruloplasmin and the precipitate obtained may not be pure ceruloplasmin. This method gives only a rough approximation of the amount of "non-ceruloplasmin" copper in serum and is of value for comparative purposes only.

Tissue copper determinations were performed by digesting 2 to $4-\mathrm{Gm}$. samples of tissue in $100-\mathrm{ml}$. Kjeldahl flasks with $2 \mathrm{ml}$. concentrated sulfuric acid and 10 to 20 ml. of concentrated nitric acid until the mixture was charred. Ten ml. of nitric acid and $1.0 \mathrm{ml}$. of concentrated perchloric acid were then added and the digestion was continued until the mixture was clear. The digests were cooled, transferred quantitatively to $10-\mathrm{ml}$. volumetric flasks and made to volume with copper-free water. Blanks containing only the reagents and a standard containing the reagents plus $20 \mu \mathrm{g}$. of copper were carried through the same digestion procedure as the samples. One-ml. aliquots of the digests were transferred to $4.0-\mathrm{ml}$. volumetric flasks. To each was added $1.0 \mathrm{ml}$. of a saturated solution of disodium hydrogen phosphate $\left(\mathrm{Na}_{2} \mathrm{HPO}_{4}\right)$ and a drop of 1.0 per cent phenolphthalein in 70 per cent ethanol. Concentrated ammonium hydroxide was then added dropwise until a definite pink color developed, after which $2 \mathrm{~N}$ hydrochloric acid was added until the pink color was faint but still readily discernible. Finally, $0.2 \mathrm{ml}$. of a saturated solution of "Cuprizone" 2 in 50 per cent ethanol was added, followed by copperfree water to volume (20). The contents of the flasks were then transferred to centrifuge tubes, allowed to stand 45 minutes, centrifuged, and the optical density was determined with a Beckman DU spectrophotometer in a $1.0-\mathrm{cm}$. cell and at a wave length of $600 \mathrm{~m} \mu$.

Urine copper determinations were performed on 20 to 40-ml. aliquots of urine. The procedure used was the same as for tissue except that a saturated solution of sodium citrate was added after the addition of sodium

\footnotetext{
2 Biscyclohexanone oxalyldihydrazone, G. F. Smith Company, Columbus, Ohio.
}

phosphate. Citrate was added in an amount (0.2 to 0.4 ml.) just sufficient to prevent the precipitation of hydroxides following the addition of ammonium hydroxide. The use of an excess amount of citrate was avoided since it inhibited subsequent color development.

The brains were weighed and one-half was saved for histologic studies. From the other half small portions (approximately 2 grams) of the brain stem, cerebellum, cerebral cortex and basal ganglion were dissected out and weighed. The white and gray matter of the cerebellum and cerebral cortex were usually analyzed separately. However, no difference in the concentration of copper was noted between the two substances and, therefore, the results are not reported separately. The remainder of the half brain was then homogenized in a Waring blendor for 3 to 4 minutes. Approximately three $\mathrm{ml}$. of copperfree water were added per gram of brain tissue. The total amount of copper in the brain was calculated from the total weight of the brain and the concentration of copper in the homogenate.

The method used for the fractionation of brain copper was essentially that of Porter and Folch (21). Total copper was determined on a $20-\mathrm{ml}$. aliquot (Fraction $\mathrm{H}$ ) of the brain homogenate. Triplicate $20-\mathrm{ml}$. aliquots were then centrifuged for 15 minutes at 15,000 times gravity in an angle-head centrifuge at room temperature. The supernatant solutions were transferred to $100-\mathrm{ml}$. digestion flasks. The three residues were washed with $10 \mathrm{ml}$. of water, centrifuged and the supernatant solutions were added to the digestion flasks. The combined supernatant solutions were then digested and analyzed for copper (Fraction Hs). The amount of copper in one of the three residues was determined after digestion $(\mathrm{Hr})$. Fifteen ml. of water were added to each of the other two residues and, after thorough mixing, the suspensions were titrated to $\mathrm{pH} 3.8$ by the addition of $0.02 \mathrm{~N}$ hydrochloric acid. The suspensions were then centrifuged at 2,000 times gravity for 10 minutes. The supernatant solutions were digested and analyzed for copper ( $\mathrm{Hr}$ II). The final residues were likewise analyzed for copper (Hr III).

Free blood ammonia levels were determined by the method of Seligson and Seligson (22) as modified by Bessman and Bessman (23). The concentration of fat in the liver was measured by the method of Folch, Ascoli, Lees, Meath, and LeBaron (24).

\section{RESULTS}

\section{Normal values}

Total serum copper, ceruloplasmin, non-ceruloplasmin copper, spinal fluid copper and urine copper values in normal subjects are presented in Table I. The values for ceruloplasmin and nonceruloplasmin copper were determined on the same 10 specimens of blood on which the total serum copper was measured (3). 
TABLE I

Blood and urine copper values in normal subjects

\begin{tabular}{|c|c|c|c|c|c|}
\hline & $\begin{array}{l}\text { Total } \\
\text { serum } \\
\text { copper }\end{array}$ & $\begin{array}{l}\text { Cerulo- } \\
\text { plasmin }\end{array}$ & $\begin{array}{l}\text { Non- } \\
\text { cerulo- } \\
\text { plasmin } \\
\text { copper }\end{array}$ & $\begin{array}{l}\text { Spinal } \\
\text { fluid } \\
\text { copper }\end{array}$ & $\begin{array}{l}\text { Urine } \\
\text { copper }\end{array}$ \\
\hline $\begin{array}{l}\text { No. } \\
\text { Mean } \\
\text { S.D.* } \\
\text { Range }\end{array}$ & $\begin{array}{c}\text { Mg./100 } \\
\text { ml. } \\
10 \\
108 \\
9 \\
92-123\end{array}$ & $\begin{array}{c}m g . / 100 \\
m l . \\
10 \\
34 \\
4 \\
27-38\end{array}$ & $\begin{array}{c}\text { me./100 } \\
\text { ml. } \\
10 \\
2.5 \dagger \\
3.7 \\
0-11\end{array}$ & $\begin{array}{c}\text { Ms./100 } \\
\text { ml. } \\
15 \\
6.2 \\
2.4 \\
3-9\end{array}$ & $\begin{array}{c}\text { re. } / 24 \\
\text { hess. } \\
20 \\
10.5 \\
6.6 \\
0-26\end{array}$ \\
\hline
\end{tabular}

* S.D. refers to standard deviation.

$t$ This figure was obtained by dividing the sum of the individual values by ten. In the four instances where the ceruloplasmin copper exceeded the total serum copper, the value for non-ceruloplasmin copper was taken as zero.

\section{Total serum copper}

The mean value for the total serum copper for the group with cirrhosis was $141 \mu \mathrm{g}$. per $100 \mathrm{ml}$., as compared with the normal mean of $108 \mu \mathrm{g}$. $(\mathrm{t}=2.64 ; \mathrm{P}=<0.02$ ) (Table II). The total serum copper level was above the upper limit of normal in 9 of the 15 patients.

A significant degree of correlation was not observed between the serum copper and the bilirubin values $(r=+0.49 ; P=>0.05)$.

\section{Ceruloplasmin}

The mean value for serum ceruloplasmin for the group was $39 \mathrm{mg}$. per $100 \mathrm{ml}$., as compared with the normal mean of $34 \mathrm{mg}$. $(\mathrm{t}=4.59 ; \mathrm{P}=0.01)$.
The values exceeded the upper limit of normal in 7 of the 15 patients.

\section{Non-ceruloplasmin copper}

The mean value for the serum non-ceruloplasmin copper for the group was $18 \mu \mathrm{g}$. per $100 \mathrm{ml}$., as compared with a mean value of $2.5 \mu \mathrm{g}$. for the control group $(t=7.7 ; P=<0.001)$. The values were greater than the upper limit of normal in 9 of the 15 patients.

\section{Spinal fluid copper}

The mean value for the spinal fluid copper for the group of patients was $15 \mu \mathrm{g}$. per $100 \mathrm{ml}$., as compared with the normal mean of $6.2 \mu \mathrm{g}$. $(\mathrm{t}=$ $2.98 ; P=0.005)$. The values were above the upper limit of normal in 7 of the 13 patients.

A significant degree of correlation was not observed between the spinal fluid and non-ceruloplasmin copper values $(r=+0.39 ; P=0.20)$.

\section{Urine copper}

The excretion of copper in the urine was increased in 5 of 8 patients (Table II). The mean value for the group was $45 \mu \mathrm{g}$. per day, as compared with $10.5 \mu \mathrm{g}$. per day in the normal subjects $(t=3.95 ; P=<0.001)$.

A significant degree of correlation was not observed between the urine and the serum non-

TABLE II

Blood and urine copper values in patients with cirrhosis of the liver

\begin{tabular}{|c|c|c|c|c|c|c|}
\hline Patient & $\begin{array}{l}\text { Total } \\
\text { serum } \\
\text { copper }\end{array}$ & $\begin{array}{l}\text { Cerulo- } \\
\text { plasmin }\end{array}$ & $\begin{array}{c}\text { Non- } \\
\text { cerulo- } \\
\text { plasmin } \\
\text { copper }\end{array}$ & $\begin{array}{l}\text { Spinal } \\
\text { fluid } \\
\text { copper }\end{array}$ & $\begin{array}{c}\text { Urine } \\
\text { copper }\end{array}$ & $\begin{array}{c}\text { Total } \\
\text { serum } \\
\text { bilirubin }\end{array}$ \\
\hline $\begin{array}{l}\text { K. R. } \\
\text { C. G. } \\
\text { E. B. } \\
\text { K. H. } \\
\text { H. L. } \\
\text { C.S. } \\
\text { G. B. } \\
\text { D. L. } \\
\text { S. L. } \\
\text { T. S. } \\
\text { J. B. } \\
\text { J. G. } \\
\text { I. O. } \\
\text { E. K. } \\
\text { D. M. }\end{array}$ & $\begin{array}{c}\text { Mg. } / 100 \mathrm{ml} \text {. } \\
225 \\
144 \\
105 \\
72 \\
147 \\
168 \\
129 \\
126 \\
114 \\
123 \\
123 \\
193 \\
180 \\
159 \\
114\end{array}$ & $\begin{array}{c}\text { mg. } / 100 \mathrm{ml} . \\
56 \\
38 \\
24 \\
19 \\
46 \\
47 \\
40 \\
34 \\
35 \\
35 \\
37 \\
47 \\
50 \\
45 \\
26\end{array}$ & $\begin{array}{c}\text { 48. } / 100 \mathrm{ml} \text {. } \\
46 \\
22 \\
28 \\
11 \\
0 \\
18 \\
1 \\
17 \\
2 \\
11 \\
5 \\
43 \\
20 \\
15 \\
31\end{array}$ & $\begin{array}{c}\mu 8 . / 100 \mathrm{ml} . \\
33 \\
18 \\
15 \\
15 \\
\\
\\
6 \\
18 \\
9 \\
12 \\
3 \\
9 \\
42 \\
9 \\
6\end{array}$ & $\begin{array}{c}\text { Mg. } / 24 \text { hrs. } \\
43 \\
9 \\
34 \\
12 \\
15 \\
40\end{array}$ & $\begin{array}{c}m \mathrm{mg} / 100 \mathrm{ml} . \\
30.0 \\
2.2 \\
4.7 \\
3.2 \\
42.4 \\
1.6 \\
1.6 \\
2.0 \\
18.0 \\
3.8 \\
\\
23.6 \\
12.5 \\
32.0 \\
14.4\end{array}$ \\
\hline $\begin{array}{l}\text { Mean } \\
\text { S.D. }\end{array}$ & $\begin{array}{c}141 \\
38.6\end{array}$ & $\begin{array}{l}39 \\
10.3\end{array}$ & $\begin{array}{l}18 \\
14.3\end{array}$ & $\begin{array}{l}15 \\
11.2\end{array}$ & $\begin{array}{l}45 \\
38.2\end{array}$ & 13.7 \\
\hline
\end{tabular}




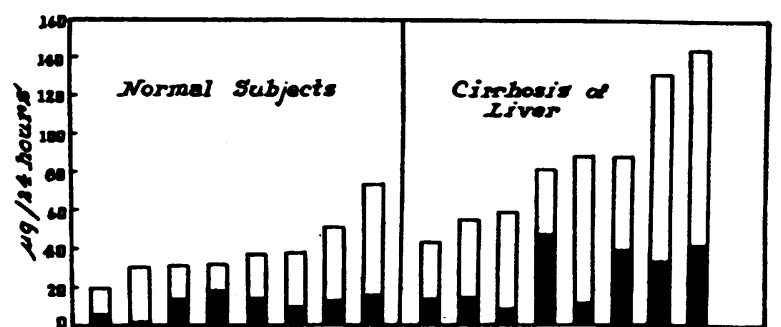

Fig. 1. The Excretion of Copper in the Urine Before aNd After the Administration of BAL

Each column represents one patient. The black portion represents the mean daily excretion of copper prior to the administration of BAL. The total column represents the excretion of copper during the 24 hours after the administration of BAL.

ceruloplasmin copper values $(r=+0.45 ; P=$ $0.25)$.

Influence of $B A L$ and of thioctic acid on the urinary excretion of copper

Total 24-hour urines were collected from eight normal subjects and eight patients with cirrhosis of the liver for four consecutive days. On the fourth day each subject was given $1.25 \mathrm{mg}$. BAL intramuscularly and the dose was repeated 12 hours later. The values for the three days prior to BAL were averaged for each patient. When BAL enhanced the excretion of copper, this occurred only during the day it was administered. Consequently, the post-BAL values shown in Figure 1 represent only those for the fourth day.

The normal subjects excreted an average of $12 \mu \mathrm{g}$. per day prior to the administration of BAL and $40 \mu \mathrm{g}$. on the day of BAL therapy (Fig-
TABLE III

Influence of thioctic acid on the urinary excretion of copper

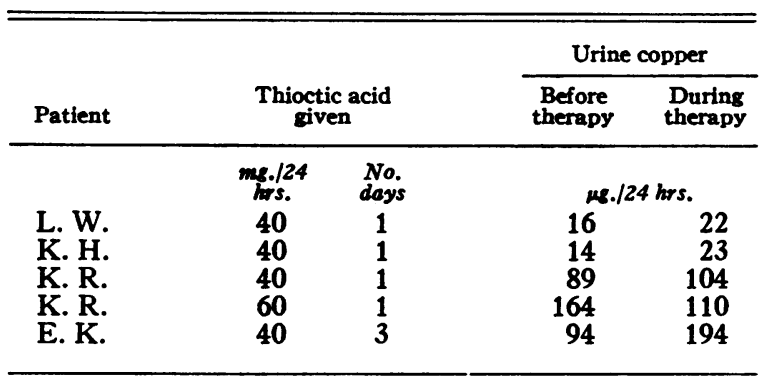

ure 1). The patients with cirrhosis excreted an average of $27 \mu \mathrm{g}$. per day prior to BAL therapy and $87 \mu \mathrm{g}$. per day on the day of BAL therapy.

The excretion of copper in the urine was studied in five patients following the intravenous administration of thioctic acid (Table III). In only one of the five patients (E. K.) was there a significant increase in the urinary excretion of copper.

\section{Influence of thioctic acid on blood copper and ammonia}

Three patients who were in hepatic coma were each given $20 \mathrm{mg}$. of thioctic acid intravenously (Table IV). Serum copper and blood ammonia levels were determined on blood from the right jugular vein, femoral artery and brachial vein and on spinal fluid obtained immediately prior to the administration of thioctic acid. Post-therapy values were obtained on $\mathrm{K}$. H. three hours later, on I. O. four hours later, and on E. K. 5 hours later.

The administration of $20 \mathrm{mg}$. of thioctic acid had no influence on the serum or spinal fluid cop-

TABLE IV

Influence of thioctic acid on serum copper and on blood ammonia

\begin{tabular}{|c|c|c|c|c|c|c|c|}
\hline \multirow[b]{2}{*}{ Specimen } & \multirow{2}{*}{ ' } & \multicolumn{2}{|c|}{ K. H. } & \multicolumn{2}{|c|}{ I. 0.} & \multicolumn{2}{|c|}{ E. $K$. } \\
\hline & & $\begin{array}{l}\text { Serum } \\
\text { copper }\end{array}$ & $\begin{array}{c}\text { Blood } \\
\text { ammonia }\end{array}$ & $\begin{array}{l}\text { Serum } \\
\text { copper }\end{array}$ & $\begin{array}{c}\begin{array}{c}\text { Blood } \\
\text { ammonia }\end{array}\end{array}$ & $\begin{array}{l}\text { Serum } \\
\text { copper }\end{array}$ & $\begin{array}{c}\text { Blood } \\
\text { ammonia }\end{array}$ \\
\hline Jugular vein & $\begin{array}{l}\text { Before } \\
\text { After }\end{array}$ & $\begin{array}{c}\mu g . / 100 \mathrm{ml} . \\
93 \\
93\end{array}$ & $\begin{array}{c}\mu \mathrm{g} . / 100 \mathrm{ml} . \\
386 \\
253\end{array}$ & $\begin{array}{c}\mu \mathrm{g} . / 100 \mathrm{ml} . \\
147 \\
159\end{array}$ & $\begin{array}{c}\mu \mathrm{\mu g} / 100 \mathrm{ml} . \\
201 \\
230\end{array}$ & $\begin{array}{c}\mu \mathrm{g} . / 100 \mathrm{ml} . \\
175 \\
160\end{array}$ & $\begin{array}{c}\mu \mathrm{g} . / 100 \mathrm{ml} . \\
278 \\
214\end{array}$ \\
\hline Femoral artery & $\begin{array}{l}\text { Before } \\
\text { After }\end{array}$ & $\begin{array}{l}93 \\
94\end{array}$ & $\begin{array}{l}371 \\
276\end{array}$ & $\begin{array}{l}150 \\
141\end{array}$ & $\begin{array}{l}180 \\
215\end{array}$ & $\begin{array}{l}153 \\
154\end{array}$ & $\begin{array}{l}326 \\
245\end{array}$ \\
\hline Brachial vein & $\begin{array}{l}\text { Before } \\
\text { After }\end{array}$ & $\begin{array}{l}90 \\
90\end{array}$ & $\begin{array}{l}272 \\
227\end{array}$ & $\begin{array}{l}150 \\
156\end{array}$ & $\begin{array}{l}127 \\
138\end{array}$ & $\begin{array}{l}160 \\
157\end{array}$ & $\begin{array}{l}266 \\
243\end{array}$ \\
\hline Spinal fluid & $\begin{array}{l}\text { Before } \\
\text { After }\end{array}$ & $\begin{array}{l}24 \\
36\end{array}$ & $\begin{array}{l}400 \\
316\end{array}$ & $\begin{array}{l}18 \\
13\end{array}$ & $\begin{array}{l}43 \\
75\end{array}$ & & $\begin{array}{l}240 \\
139\end{array}$ \\
\hline
\end{tabular}


TABLE $\mathbf{v}$

Tissue copper *

\begin{tabular}{|c|c|c|c|c|c|c|c|c|c|c|}
\hline \multirow{2}{*}{$\begin{array}{l}\text { Subject } \\
\text { Normals }\end{array}$} & \multicolumn{2}{|c|}{ Liver } & \multicolumn{2}{|c|}{ Heart } & \multicolumn{2}{|c|}{ Kidney } & \multicolumn{2}{|c|}{ Spleen } & \multirow{2}{*}{$\begin{array}{c}\begin{array}{c}\text { Psoas } \\
\text { muscle }\end{array} \\
\begin{array}{c}\mu g . / G m . \\
0.9\end{array} \\
(0.6-1.0)\end{array}$} & \multirow{2}{*}{$\begin{array}{c}\text { Bile } \\
\mu g . / 100 \mathrm{ml} \\
329 \\
(24-538)\end{array}$} \\
\hline & $\begin{array}{c}\mu \mathrm{\mu g} / \mathrm{Gm} . \\
5.3 \\
(3.0-9.5)\end{array}$ & $\begin{array}{c}\text { mg. } \\
\stackrel{8.5}{(3.6-13.1)}\end{array}$ & $\begin{array}{c}\text { M8./Gm. } \\
3.2 \\
(2.8-3.8)\end{array}$ & $\begin{array}{c}\text { mg. } \\
1.0 \\
(0.9-1.2)\end{array}$ & $\begin{array}{c}\text { Mg./Gm. } \\
2.2 \\
(1.8-3.1)\end{array}$ & $\begin{array}{c}m g . \\
0.97 \\
(0.2)\end{array}$ & $\begin{array}{c}\mu \mathrm{g} . / \mathrm{Gm} . \\
1.0 \\
(0.7-1.1)\end{array}$ & $\begin{array}{c}m g . \\
0.1 \\
(0.1-0.2)\end{array}$ & & \\
\hline $\begin{array}{l}\text { H. L. } \\
\text { S. L. } \\
\text { A.S. } \\
\text { J. B. } \\
\text { E. K. } \\
\text { I. O. } \\
\text { D. M. } \\
\text { J.G. } \\
\text { W. H. } \\
\text { L. C. } \\
\text { P. S. } \\
\text { F. H. }\end{array}$ & $\begin{array}{r}7.0 \\
3.5 \\
7.6 \\
5.8 \\
3.4 \\
15.0 \\
8.0 \\
29.7 \\
3.9 \\
4.1 \\
17.1 \\
8.2\end{array}$ & $\begin{array}{r}17.6 \\
5.4 \\
10.7 \\
12.8 \\
12.6 \\
37.2 \\
20.1 \\
41.0 \\
10.4 \\
8.0 \\
34.2 \\
18.5\end{array}$ & $\begin{array}{l}2.9 \\
3.4 \\
2.0 \\
2.4 \\
2.5 \\
2.7 \\
3.6 \\
2.3 \\
2.4 \\
2.4\end{array}$ & $\begin{array}{l}1.0 \\
1.0 \\
0.7 \\
0.9 \\
1.3 \\
0.9 \\
1.3 \\
0.7 \\
1.1 \\
0.9\end{array}$ & $\begin{array}{l}1.7 \\
1.7 \\
3.5 \\
2.4 \\
3.3 \\
2.1 \\
1.6 \\
2.2 \\
2.3 \\
1.7 \\
2.6 \\
1.9\end{array}$ & $\begin{array}{l}0.9 \\
0.6 \\
0.9 \\
0.8 \\
0.8 \\
0.8 \\
0.7 \\
1.0 \\
0.6 \\
0.5 \\
1.5 \\
0.6\end{array}$ & $\begin{array}{r}1.2 \\
0.9 \\
1.0 \\
1.1 \\
1.0 \\
1.1 \\
1.1 \\
1.5 \\
1.0 \\
0.9\end{array}$ & $\begin{array}{l}0.5 \\
0.2 \\
0.7 \\
0.2 \\
0.4 \\
0.3 \\
0.1 \\
0.1 \\
0.2 \\
0.2\end{array}$ & $\begin{array}{l}0.5 \\
0.8 \\
0.5 \\
0.9\end{array}$ & $\begin{array}{r}160 \\
171 \\
220 \\
350 \\
17 \\
2,870 \\
979\end{array}$ \\
\hline Mean & 9.4 & 19.0 & 2.6 & 1.0 & 2.2 & 0.8 & 1.1 & 0.3 & 0.7 & 681 \\
\hline
\end{tabular}

* The values are expressed in $\mu \mathrm{g}$. per gram of wet tissue and in mg. in the whole organ.

per. However, in two of the patients (K. H. and E. K.) there was an appreciable decrease in the blood and spinal fluid ammonia levels. The decrease in ammonia in these two patients was associated with signs of improvement in the clinical state.

Serum copper was studied in four patients prior to the development of hepatic coma, during hepatic coma, and after the mental state had cleared and the neurologic manifestations had disappeared. A significant change in the total serum copper concentration was not observed in any of the patients.

\section{Tissue copper}

The amount of copper in the liver, heart, kidney, spleen, psoas muscle and bile was determined in 12 patients with cirrhosis of the liver (Table V).

The mean value for the concentration of copper in the liver was $9.4 \mu \mathrm{g}$. per $\mathrm{Gm}$. of wet tissue as compared with $5.3 \mu \mathrm{g}$. per $\mathrm{Gm}$. in the five normal subjects. The values were above the upper limit of normal in only four of the 12 patients. However, the concentration of fat in a number of the livers was increased and this would reduce the

TABLE VI

Brain copper *

\begin{tabular}{|c|c|c|c|c|c|c|c|c|}
\hline \multirow{3}{*}{$\begin{array}{l}\text { Subjects } \\
\text { Normals }\end{array}$} & & & \multirow{3}{*}{$\begin{array}{c}\begin{array}{c}\text { Brain } \\
\text { stem }\end{array} \\
\mu g . / G m . \\
2.6 \\
(2.0-3.0)\end{array}$} & \multirow{3}{*}{$\begin{array}{c}\text { Cerebellum } \\
\text { mg./Gm. } \\
6.5 \\
(4.6-7.9)\end{array}$} & \multirow{3}{*}{$\begin{array}{c}\begin{array}{c}\text { Cerebral } \\
\text { cortex }\end{array} \\
\mu g . / G m . \\
4.2 \\
(3.9-4.7)\end{array}$} & \multirow{3}{*}{$\begin{array}{c}\begin{array}{c}\text { Basal } \\
\text { ganglion }\end{array} \\
\mu g . / G m . \\
5.7 \\
(4.4-6.8)\end{array}$} & \multicolumn{2}{|c|}{ Spinal cord } \\
\hline & \multicolumn{2}{|c|}{ Whole brain } & & & & & Cervical & $\begin{array}{l}\text { Lower } \\
\text { thoracic }\end{array}$ \\
\hline & $\begin{array}{c}\mu g . / G m . \\
6.3 \\
(5.1-8.3)\end{array}$ & $\begin{array}{c}m g . \dagger \\
8.0 \\
(7.4-10.1)\end{array}$ & & & & & $\begin{array}{c}\mu g . / \mathrm{Gm} . \\
1.7 \\
(0.3-3.0)\end{array}$ & $\mu g . / G m$. \\
\hline $\begin{array}{l}\text { H. L. } \\
\text { S. L. } \\
\text { A. S. } \\
\text { J. B. } \\
\text { E. K. } \\
\text { I. O. } \\
\text { D. M. } \\
\text { W. H. } \\
\text { L. C. }\end{array}$ & $\begin{array}{r}6.9 \\
5.1 \\
6.3 \\
5.7 \\
6.3 \\
10.2 \\
7.2 \\
7.7 \\
3.5\end{array}$ & $\begin{array}{r}9.8 \\
6.0 \\
8.7 \\
8.5 \\
7.6 \\
13.9 \\
10.8 \\
10.4 \\
3.8\end{array}$ & $\begin{array}{l}5.2 \\
3.6 \\
4.9 \\
4.0 \\
3.5 \\
4.6 \\
6.1 \\
4.5 \\
3.2\end{array}$ & $\begin{array}{l}6.4 \\
5.4 \\
8.2 \\
7.2 \\
6.7 \\
6.5 \\
8.2 \\
7.4 \\
3.5\end{array}$ & $\begin{array}{l}5.9 \\
4.2 \\
5.0 \\
4.5 \\
4.6 \\
5.0 \\
7.4 \\
5.9 \\
2.7\end{array}$ & $\begin{array}{r}5.4 \\
6.1 \\
7.4 \\
8.1 \\
10.3 \\
7.3 \\
5.0\end{array}$ & $\begin{array}{l}0.7 \\
1.2 \\
1.7\end{array}$ & $\begin{array}{l}3.4 \\
3.0 \\
\\
5.2 \\
4.1 \\
4.2 \\
\\
6.2 \\
2.0\end{array}$ \\
\hline Mean & 6.5 & 8.8 & 4.4 & 6.6 & 5.0 & 7.1 & 1.2 & 4.0 \\
\hline
\end{tabular}

* The values are expressed in $\mu \mathrm{g}$. per gram of wet tissue.

$\dagger$ Total mg. in the whole brain. 
concentration of copper per gram of tissue. For example, the percentage of fat in six of the livers with normal copper concentrations was as follows: J. B., 29; D. M., 26; S. L., 26; W. H., 24 ; L. D., 18; and H. L., 12 . In two patients (I. O. and J. G.) with increased concentrations of copper the fat content was increased only slightly -7 and 6 per cent, respectively. The percentage of fat in the normal livers ranged from 3 to 5 .

The total amount of copper in the liver was increased above the upper limit of normal in 6 of the 12 patients with cirrhosis of the liver.

The amount of copper in the liver was greatly increased in three of the patients (J.: G., I. O. and P. S.). The mean value for the group of patients with cirrhosis was 2.2 times greater than the normal mean.

The amount of copper in heart, kidneys, and psoas muscle was not increased significantly. In four of the patients there was a slight increase in the total amount of copper in the spleen. The concentration of copper in the bile varied considerably in both the "normal" subjects and the patients. Likewise, the viscosity of the bile varied considerably from sample to sample; extremely viscous, almost solid bile samples contained the highest concentration of copper.

The mean concentration and total amount of copper in the brains of nine patients with cirrhosis of the liver did not differ significantly from the normal (Table VI). In only three patients (I. O., D. M., and W. H.) was the amount of copper increased. In two of these (D. M. and W. H.) the values were only slightly above the upper limit of normal. In general, in those cases with the greatest amount of copper in the liver, the greatest amount of copper was found in the brain. The correlation coefficient between liver and brain copper was $+0.84(\mathrm{P}=<0.01)$.

The concentration of copper in the brain stem was increased in all nine of the patients; in the cerebellum in two patients; in the cerebral cortex in five patients; and in the basal ganglion in four of seven patients. However, in none of these areas was there a very great increase in the concentration of copper as compared with the normal subjects. The concentration of copper in the cervical region of the spinal cord was not increased. The concentration of copper in the lower
TABLE VII

Brain copper fractionation *

\begin{tabular}{lcccccc}
\hline \hline Subjects & \multicolumn{2}{c}{ Homogenate (H) } & Hs & Hr & Hr II & Hr III \\
\hline & M8./Gm. & $\%$ & $\%$ & $\%$ & $\%$ & $\%$ \\
Normals & 6.0 & 100 & 58 & 42 & 9 & 34 \\
& $(5.1-8.3)$ & & $(51-61)$ & $(40-50)$ & $(7-12)$ & $(25-43)$ \\
H. L. & 6.9 & 100 & 69 & 28 & 7 & 27 \\
S. L. & 5.1 & 100 & 69 & 30 & 4 & 25 \\
A.S. & 6.3 & 100 & 68 & 28 & 5 & 21 \\
J.B. & 5.7 & 100 & 72 & 28 & 6 & 24 \\
E. K. & 6.3 & 100 & 75 & 31 & 6 & 27 \\
I. O. & 10.2 & 100 & 60 & 38 & 7 & 33 \\
D. M. & 7.2 & 100 & 75 & 26 & 4 & 22 \\
W. H. & 7.7 & 100 & 72 & 28 & 5 & 25 \\
L. C. & 3.5 & 100 & 65 & 36 & 9 & 28 \\
Mean & 6.5 & 100 & 70 & 30 & 6 & 26 \\
\hline
\end{tabular}

* For symbols see text.

thoracic region of the spinal cord was greater than in the cervical area but, unfortunately, at the time these studies were performed this regional difference was not appreciated and spinal cord was not obtained from the thoracic area of the "normal" subjects.

The partition of copper in the brains of the patients with cirrhosis of the liver was significantly different from that of the "normal" subjects (Table VII). In the brains of the former, a greater portion of the copper remained in the aqueous supernatant solution after homogenization (Fraction Hs) and a greater portion of the copper remaining in the residue was released into solution after decreasing the $\mathrm{pH}$ to 3.8 (Fraction Hr III).

\section{DISCUSSION}

The results of this study indicate that in some patients with cirrhosis of the liver there are significant alterations in the metabolism of copper. In particular, it appears that the fraction of copper which is "loosely bound" to proteins is increased. Thus, there was a significant increase in the "non-ceruloplasmin" fraction of copper in serum, an increase in the amount of copper in urine and spinal fluid, and a greater proportion of the brain copper remained in aqueous solution after homogenization. The increased amount of copper in the urine and spinal fluid is probably a reflection of the increased amount of "nonceruloplasmin" copper in the serum. Failure to observe a good correlation between the "nonceruloplasmin" copper in serum and the amount 
of copper in the spinal fluid and urine can probably be accounted for by the difficulty in measuring the serum fraction directly and accurately.

The possible role of estrogens in the pathogenesis of the hypercupremia associated with cirrhosis of the liver is worthy of comment. Hypercupremia may be produced in human subjects by estrogen administration (25) and is present in pregnant women (26) in whom there is a high level of circulating estrogens. In subjects with cirrhosis of the liver, there are many manifestations of excessive estrogenic stimulation because of the diminished capacity of the liver to "inactivate" the circulating estrogens (27). The observed hypercupremia may possibly be the consequence of estrogenic activity.

That the alterations in copper metabolim found in these patients account for the neuropsychiatric manifestations of this disease seems unlikely. The changes were not particularly pronounced and were not present in all patients even in the presence of severe liver disease and coma. Furthermore, the degree of alteration did not correlate with the presence or absence of coma. Thirdly, increases in "non-ceruloplasmin" copper as great or greater than those which have been observed in patients with cirrhosis have been found in pregnant women and in patients with infections in the absence of such neuropsychiatric manifestations (3). Finally, in five of the ten patients who died in hepatic coma there was no increase in total liver copper. Total brain copper was measured in eight of these patients and was found to be within the limits of normal in five. Thus, in agreement with Porter and Adams (15), we must conclude that there does not seem to be a correlation between hepatic coma and the total copper content of either the brain or the liver.

In three of the patients (I. O., D. G. and P. S.) there was a striking increase in both the concentration and total amount of copper in the liver. In these patients the total amount of copper in the liver approached the values which we have observed in Wilson's disease (49 to $124 \mathrm{mg}$.) (28). In an attempt to determine why so much more copper was present in the livers of these patients than in the livers of the other cases of cirrhosis, the clinical and pathological records were scrutinized carefully. No correlation was found between the amount of copper in the liver and the duration of liver disease or the degree or duration of jaundice. Likewise, no correlation was found between the amount of copper in the liver and the amount of fibrosis or the degree of fatty infiltration. However, in all three of the above cases with greatly elevated hepatic copper levels, in contradistinction to the other autopsied cases, there was neutrophilic infiltration in and around the small bile ducts and inspissated bile was prominent. Thus it appears that the hepatic copper level was greatly elevated in those patients with cirrhosis and associated cholangiolitis and was not increased in those without some degree of cholangiolitis. Since it has been demonstrated $(4,29,30)$ that the bile is the main excretory route for copper, it is not surprising to observe that in patients with cholangiolitis there is impairment of the excretion of copper into the bile and retention of this element in the liver. To substantiate this hypothesis, the amount of copper in the liver of a young woman who died of classical primary biliary cirrhosis with xanthomatosis was determined and was found to be $426 \mathrm{mg}$. (28). These observations suggest that it would be of some interest to study copper metabolism in patients with obstructive biliary tract disease.

\section{SUM MARY}

1. Alterations in copper metabolism have been studied in a group of patients with Laennec's cirrhosis of the liver.

2. The mean value ( \pm standard deviation) for the total serum copper was $141 \pm 38.6 \mu \mathrm{g}$. per 100 $\mathrm{ml}$. ; for ceruloplasmin, $39 \pm 10.3 \mathrm{mg}$. per $100 \mathrm{ml}$; for "non-ceruloplasmin" serum copper, $18 \pm 14.3$ $\mu \mathrm{g}$. per $100 \mathrm{ml}$.; for spinal fluid copper, $15 \pm 11.2$ $\mu \mathrm{g}$. per $100 \mathrm{ml}$; for urine copper, $45 \pm 38.2 \mu \mathrm{g}$. per 24 hours. Values in normal subjects were as follows: total serum copper, $108 \pm 9 \mu \mathrm{g}$. per 100 ml. ; ceruloplasmin, $34 \pm 4 \mathrm{mg}$. per $100 \mathrm{ml}$.; "nonceruloplasmin" serum copper, $2.5 \pm 3.7 \mu \mathrm{g}$. per $100 \mathrm{ml}$.; spinal fluid copper, $6.2 \pm 2.4 \mu \mathrm{g}$. per 100 ml. ; urine copper, $10.5 \pm 6.6 \mu \mathrm{g}$. per 24 hours.

3. Following the administration of $\mathrm{BAL}$ the patients excreted an average of $87 \mu \mathrm{g}$. of copper in the urine daily whereas the normal subjects excreted an average of $40 \mu \mathrm{g}$. Thioctic acid had no influence on the amount of copper excreted in the urine of the patients in either group. 
4. The mean value for the total amount of copper in the liver of 12 patients with cirrhosis was $19 \mathrm{mg}$. as compared with a value of $8.5 \mathrm{mg}$. in five "normal" subjects. In six of the patients there was a normal amount of copper in the liver. In three of the patients there was a greatly increased amount of copper in this organ. The amount of copper in the heart, kidneys, muscle and spleen was not increased significantly from the normal.

5. The mean value for the total amount of copper in the brain of nine patients with cirrhosis was $6.5 \mathrm{mg}$. as compared with a value of $6.0 \mathrm{mg}$. in five "normal" subjects.

6. It is concluded from these studies that it is unlikely that the alterations in copper metabolism are of any significance in the pathogenesis of the neuropsychiatric manifestations of Laennec's cirrhosis of the liver.

7. It is suggested that in patients with cirrhosis and an associated cholangiolitis the excretion of copper into the bile is impaired and this results in retention of the element in the liver.

\section{ACKNOWLEDGMENTS}

We are indebted to Miss Marilyn Jacobson for technical assistance. The thioctic acid was kindly supplied by Dr. T. H. Jukes and Dr. J. M. Ruegsegger of Lederle Laboratories, Pearl River, New York. Dr. J. H. Brewer of Hynson, Westcott and Dunning, Baltimore, Maryland, generously furnished the BAL.

\section{REFERENCES}

1. Bearn, A. G., and Kunkel, H. G., Abnormalities of copper metabolism in Wilson's disease and their relationship to the aminoaciduria. J. Clin. Invest., 1954, 33, 400.

2. Cartwright, G. E., Hodges, R. E., Gubler, C. J., Mahoney, J. P., Daum, K., Wintrobe, M. M., and Bean, W. B., Studies on copper metabolism. XIII. Hepatolenticular degeneration. J. Clin. Invest., 1954, 33, 1487.

3. Markowitz, H., Gubler, C. J., Mahoney, J. P., Cartwright, G. E., and Wintrobe, M. M., Studies on copper metabolism. XIV. Copper, ceruloplasmin and oxidase activity in sera of normal human subjects, pregnant women, and patients with infection, hepatolenticular degeneration, and the nephrotic syndrome. J. Clin. Invest., 1955, 34, 1498.

4. Bush, J. A., Mahoney, J. P., Markowitz, H., Gubler, C. J., Cartwright, G. E., and Wintrobe, M. M., Studies on copper metabolism. XVI. Radioactive copper studies in normal subjects and in patients with hepatolenticular degeneration. J. Clin. Invest., 1955, 34, 1766.

5. Summerskill, W. H. J., Davidson, E. A., Sherlock, S., and Steiner, R. E., The neuropsychiatric syndrome associated with hepatic cirrhosis and an extensive portal collateral circulation. Quart. J. Med., 1956, 25, 245.

6. Mallory, F. B., The relation of chronic poisoning with copper to hemochromatosis. Am. J. Path., 1925, $1,117$.

7. Mallory, F. B., Hemochromatosis and chronic poisoning with copper. Arch. Int. Med., 1926, 37, 336.

8. Adams, R. D., and Foley, J. M., The neurological disorder associated with liver disease in Metabolic and Toxic Diseases of the Nervous System, Merritt, H. H., and Hare, C. C., Eds. A Research Publication, Research Nerv. \& Ment. Dis. Proc., 1953, 32, 198.

9. Heilmeyer, L., Keiderling, W., and Stüwe, G., Kupfer und Eisen als körpereigene Wirkstoffe und ihre Bedeutung beim Krankheitsgeschehen. Fischer, Jena, 1941.

10. Locke, A., Main, E. R., and Rosbash, D. O., The copper and nonhemoglobinous iron contents of the blood serum in disease. J. Clin. Invest., 1932, 11, 527.

11. Butzengeiger, K. H., and Lange, J., "Uber das Verhalten des Eisen-und Kupferspiegels im Blut bei Erkrankungen der Leber und der Gallenwege. Deut. Arch. Klin. Med., 1952, 199, 633.

12. Cumings, J. N., The copper and iron content of brain and liver in the normal and in hepato-lenticular degeneration. Brain, 1948, 71, 410.

13. Schoenheiner, R., and Herkel, W., Uber die Bedeutung des Kupfers für die Lebercirrhose. Klin. Wchnschr., 1930, 9, 1449.

14. Gerlach, W., Untersuchungen über den Kupfergehalt menschlicher (und tierischer) Organe. Arch. Path. Anat., 1934, 294, 171.

15. Porter, H., and Adams, R. D., The copper content of brain and liver in hepatic encephalopathy. J. Neuropath. \& Exper. Neurol., 1956, 15, 61.

16. Thompson, C. M., Gambescia, J. M., Lisan, P., and Fuschs, M., Addition of thioctic acid to a plan for management of hepatic insufficiency. Am. J. Med., 1956, 21, 131.

17. Steigmann, F., and Canahuati, S. M., Thioctic acid in the treatment of hepatic coma. Federation Proc., 1956, 15, 487.

18. Gubler, C. J., Lahey, M. E., Ashenbrucker, H., Cartwright, G. E., and Wintrobe, M. M., Studies on copper metabolism. I. A method for the determination of copper in whole blood, red blood cells, and plasma. J. Biol. Chem., 1952, 196, 209.

19. Gubler, C. J., Lahey, M. E., Cartwright, G. E., and Wintrobe, M. M., Studies on copper metabolism. IX. The transportation of copper in blood. J. Clin. Invest., 1953, 32, 405.

20. Peterson, R. E., and Bollier, M. E., Spectrophotometric determination of serum copper with biscyclo- 
hexanoneoxalyldihydrazone. Anal. Chem., 1955, 27, 1195.

21. Porter, H., and Folch, J., Fractionation of brain copper proteins. Federation Proc., 1954, 13, 275.

22. Seligson, D., and Seligson, H., A microdiffusion method for the determination of nitrogen liberated as ammonia. J. Lab. \& Clin. Med., 1951, 38, 324.

23. Bessman, S. P., and Bessman, A. N., The cerebral and peripheral uptake of ammonia in liver disease with an hypothesis for the mechanism of hepatic coma. J. Clin. Invest., 1955, 34, 622.

24. Folch, J., Ascoli, I., Lees, M., Meath, J. A., and LeBaron, F. N., Preparation of lipide extracts from brain tissue. J. Biol. Chem., 1951, 191, 833.

25. Russ, E. M., and Raymunt, J., Influence of estrogens on total serum copper and caeruloplasmin. Proc. Soc. Exper. Biol. \& Med., 1956, 92, 465.
26. Fay, J., Cartwright, G. E., and Wintrobe, M. M., Studies on free erythrocyte protoporphyrin, serum iron, serum iron-binding capacity and plasma copper during normal pregnancy. J. Clin. Invest., 1949, 28, 487.

27. Lloyd, C. W., and Williams, R. H., Endocrine changes associated with Laennec's cirrhosis of the liver. Am. J. Med., 1948, 4, 315.

28. Cartwright, G. E., Gubler, C. J., and Wintrobe, M. M., Unpublished observations.

29. Van Ravesteyn, A. H., Metabolism of copper in man. Acta med. Scandinav., 1944, 118, 163.

30. Mahoney, J. P., Bush, J. A., Gubler, C. J., Moretz, W. H., Cartwright, G. E., and Wintrobe, M. M., Studies on copper metabolism. XV. The excretion of copper by animals. J. Lab. \& Clin. Med., $1955,46,702$. 